\section{Gonadotrophin deficiency and adrenocortical insufficiency in children: a new syndrome}

In 1962 this patient was described by one of us (GWP) as a rare case of Addison's disease in a 6-year-old child. At the age of 23, the patient, it is now apparent, has an even rarer condition-namely, the association of hypogonadotrophic hypogonadism with congenital adrenal hypoplasia.

\section{Case report}

The patient was born in 1953 after a normal pregnancy during which his mother took no drugs. From the age of 4 years he vomited frequently, and at 5 years developed a craving for salt. Aged 6, he was easily fatigued, had abdominal pain and vomiting, and became severely ill. Generalised pigmentation together with hypothermia and hypotension led to his admission with a diagnosis of Addison's disease, subsequently confirmed biochemically. ${ }^{1}$ Treatment with cortisone and deoxycorticosterone acetate resulted in dramatic improvement in vigour and loss of abnormal pigmentation.

In 1975, aged 21, he was referred for further investigation because of failure to achieve sexual maturity. He had some pubic but no axillary or facial hair; his voice was high-pitched; and his genitalia were small. His sense of smell was normal and he appeared euthyroid and euadrenal. Both parents, two brothers aged 13 and 18 years, and a sister aged 15 years were all well with normal sexual development. No siblings had died early in childhood. In July 1975 the serum testosterone concentration was $6 \cdot 4 \mathrm{nmol} / 1(1.82 \mathrm{ng} / \mathrm{ml})$ (normal 9-24 nmol/1). Basal serum luteinising hormone concentration was $2 \mathrm{U} / \mathrm{l}$ (normal 3-8) and failed to exceed $4 \mathrm{U} / \mathrm{l}$ (normal $>8$ ) after gonadotrophin releasing hormone ( $\mathrm{GnRH}), 100 \mu \mathrm{g}$ intravenously. Serum follicle stimulating hormone concentration was $2.9 \mathrm{U} / 1$ (normal 2-7) and did not increase after administration of GnRH. While he was temporarily on dexamethasone, daily injections of 40 units ACTH for 17 days caused no increase in plasma cortisol concentration. The results of pituitary-thyroid axis tests were normal, random growth hormone concentration was $23 \mu \mathrm{g} / 1$ (normal), and serum prolactin concentration $16 \mu \mathrm{g} / \mathrm{l}$ (normal 5-25). Circulating antibodies to pituitary and adrenal tissue were not detected. Pituitary fossa radiographs were normal, and bone age was 17 years. The karyotype was $46 \mathrm{XY}$.

Treatment was begun with human chorionic gonadotrophin, 2000 units intramuscularly once weekly, and serum testosterone levels increased and have remained within the normal adult male range. He has become virilised with axillary and pubic hair growth, and increase in libido with spontaneous erections.

\section{Comment}

In 1975 Prader et $a l^{2}$ reported the case of a man of 18 who had developed adrenal insufficiency one week after birth, resistant to treatment with corticotrophin, improving with cortisone, but later needing deoxycorticosterone. Later, he had delayed sexual maturation and isolated gonadotrophin deficiency was found. A brother had died 18 hours after birth, and no adrenal glands were found at necropsy. Prader et al speculated that the association of congenital adrenal hypoplasia with gonadotrophin failure might constitute a syndrome. Most children with congenital adrenal hypoplasia die within a few weeks if untreated. ${ }^{3-4}$ There are two forms with distinctive adrenal lesions.

We were writing up our case when our attention was drawn to a second case of this syndrome. ${ }^{5}$ Interestingly, our patient has three unaffected siblings, including two brothers, and he has survived untreated to the age of 6 years. He is now the oldest survivor known to have this double defect. In our experience, patients with classical Addison's disease treated since childhood do not usually have problems with sexual maturation or fertility.

No connection is obvious between the two endocrine defects in our patient. The syndrome will presumably be recognised more frequently now that cortisone-treated children will be surviving long enough to manifest the hypogonadal component.

We thank Dr A Batty Shaw, consultant physician of Norwich for permission to publish details of this patient; also Drs $F$ Newman, $K$ Mashiter, J M Kjeld, and P Sönksen for hormone assays; Dr W J Irvine for estimating pituitary and adrenal antibodies; and Dr E Vogl of Hoechst (UK) Ltd for supplies of GnRH.

1 Pearson, G W, British Medical fournal, 1962, 1, 1057

2 Prader, A, et al, fournal of Pediatrics, 1975, 86, 421.

${ }^{3}$ Brook, C G D, et al, Helvetica Paediatrica Acta, 1973, 28, 277.

4 Kerenyi, N, Archives of Pathology and Laboratory Medicine, 1961, 71, 336

5 Brook, C G D, and Cox, J P N. Case presented at Royal Society of Medicine, London, 24 November 1976.

(Accepted 18 March 1977)

Endocrine Unit, Department of Medicine, Royal Postgraduate Medical School, Hammersmith Hospital, London W12 0HS

W F KELLY, BSC, MRCP, registrar

G F JOPLIN, PHD, FRCP, consultant physician

Elmham, Norfolk

G W PEARSON, MB, BCHIR, general practitioner

\section{A caecal diaphragm}

An extensive search of published reports failed to find a case of a diaphragm of the caecum or similar abnormality. The case described here is therefore believed to be the first recorded.

\section{Case report}

A 47-year-old Bangladeshi man, who had lived in Britain for five years, had a partial gastrectomy for a benign mid-lesser curve ulcer in Novembe 1974. His recovery from the operation was uneventful. At follow-up in December 1975 he complained of intermittent central abdominal colic. Each attack was followed by several days of watery diarrhoea then two or three days of constipation.

Examination showed no abdominal swellings and sigmoidoscopy showed a normal rectal mucosa. The results of investigations were: haemoglobin $13.6 \mathrm{~g} / \mathrm{dl}$, white cell count $6.9 \times 10^{9} / 1$, and erythrocyte sedimentation rate $2 \mathrm{~mm}$ in the first hour; urea, serum electrolytes, and serum protein concentrations and liver function were all normal; microscopy and culture of his stools showed no pathogenic organisms, and there was no faccal occult blood. A barium meal and follow-through examination showed a normal gastric remnant, jejunum, and ileum. A filling defect was noted in the lower pole of the caecum, which persisted despite palpation of the caecum by the examining radiologist during screening. These findings were confirmed by barium enema examination (see figure). A chest radiograph showed no abnormality. Tests of sputum, stools, and urine for Mycobacterium tuberculosis were negative.

After bowel preparation laparotomy was performed. The only abnormality noted was a hard distended caecal pole containing faeces which could not be moved onwards into the ascending colon. After appendicectomy a longitudinal caecotomy was performed, which displayed a mixture of faeces and barium in the caecum. Extraction of the faeces and barium disclosed a diaphragm of the caecal pole lying about $1.5 \mathrm{~cm}$ below the ileocaecal valve and having a small central lumen. The diaphragm was incised in a radial fashion to its central aperture. The diaphragm was rigid with mucosa on the upper and lower surfaces and had a central core of fibrous tissue, thus appearing to be congenital in origin. A biopsy specimen was not taken. The caecotomy was closed in a horizontal fashion with interrupted sutures. His postoperative course was satisfactory, and since his discharge from hospital he has had no further abdominal symptoms and his bowel habit has returned to normal. A repeat barium study showed that contrast medium entered the caecal pole.

\section{Comment}

A caecal diaphragm must be regarded as rare and probably congenital in origin. The presenting symptoms in our patient were most probably unrelated to the caecal diaphragm and due to a transient gastrointestinal infection. The finding of a diaphragm was thus fortuitous but the $x$-ray appearances it caused might well have indicated a neoplasm or chronic inflammatory lesion and made a 


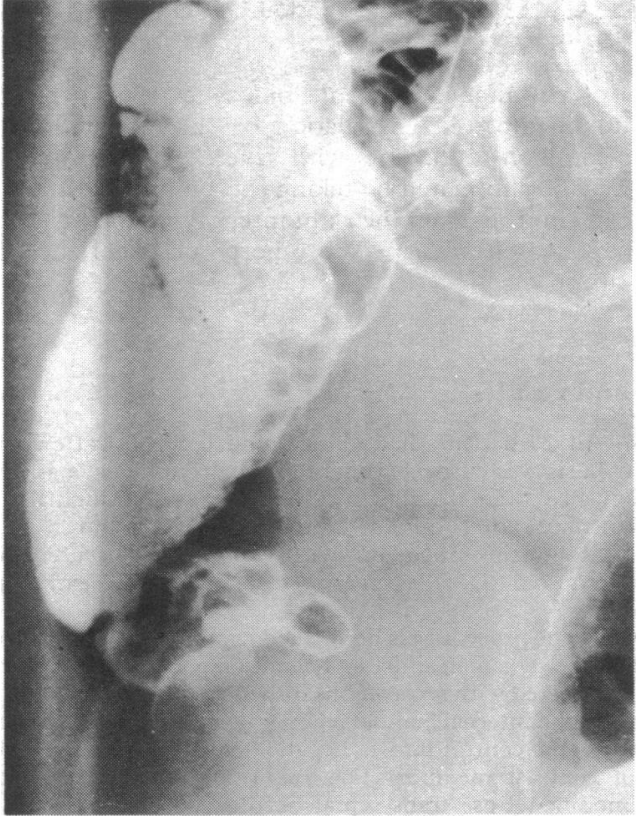

Filling defect in lower pole of caecum.

laparotomy mandatory. A caecal diaphragm must therefore become part of the differential diagnosis of a space-occupying lesion of the lower pole of the caecum found by radiology. The chance of diagnosing correctly a caecal diaphragm by radiology alone must be remote, but if at laparotomy for suspected pathology of the pole of the caecum faeces are palpated in the caecal pole and attempts to move them into the ascending colon fail then the presence of a caecal diaphragm must be seriously considered.

(Accepted 18 March 1977)

Bradford Royal Infirmary, West Yorkshire

A D GAYNER, FRCS, registrar

J J PRICE, FRCs, consultant surgeon

O J FOLLOWS, MRCP, FRCR, consultant radiologist

\section{Giant-cell arteritis and hypothyroidism}

The aetiology of giant-cell arteritis is unknown, though there is increasing evidence to suggest an immunological basis in which the arterial elastic tissue acts as an antigen. ${ }^{12}$ An association of giant-cell arteritis with currently well-recognised autoimmune disorders would therefore be of interest and might provide indirect supporting evidence of an underlying abnormal immune host response. The simultaneous presentation of giant-cell arteritis and autoimmune thyroiditis with hypothyroidism has not previously been reported.

\section{Case report}

A 73-year-old woman was admitted to hospital with a 12-month history of lethargy and depression for which antidepressants had been prescribed. During the previous six weeks she had also complained of intolerance to cold, acroparaesthesiae, and bitemporal headaches. Relatives had noticed her to be slow and reported the recent appearance of puffiness around the eyes and hoarseness. She denied any visual disturbance, muscle pain, or joint stiffiness and there was no history of endocrine disease.

On examination she looked myxoedematous with dry skin and periorbital puffiness. The thyroid was moderately enlarged and the relaxation phase of ankle jerks was slow. Both superficial temporal arteries were clinically normal, pulsatile, and non-tender. There were no abnormal vascular bruits, and all peripheral pulses were present. The locomotor system showed no abnormality. Results of investigations were: haemoglobin $9.9 \mathrm{~g} / \mathrm{dl}$, erythrocyte sedimentation rate (ESR) $115 \mathrm{~mm}$ in first hour, protein-bound iodine (PBI) $250 \mathrm{nmol} / 1$ $(3.2 \mu \mathrm{g} / 100 \mathrm{ml}$ ) (normal 315-630 nmol/1 $(4 \cdot 0-8.0 \mu \mathrm{g} / 100 \mathrm{ml})$ ), and four-hour thyroidal uptake of ${ }^{132}$ I $5 \cdot 4 \%$ (normal $10-35 \%$ ). Anticytoplasmic thyroid antibody titre was strongly positive and antithyroglobulin antibody titre positive at $1 / 2.5 \times 10 .^{6}$ Antigastric antibody titre was negative, and serum vitamin $B_{12}$ and folate concentrations were within the normal ranges. Biopsy of a right superficial temporal artery showed the characteristic changes of giant-cell arteritis.

The patient was treated with oral prednisolone $40 \mathrm{mg}$ daily and at the same time began thyroxine replacement therapy $50 \mu \mathrm{g}$ daily, later gradually increased to $200 \mu \mathrm{g}$ daily. Within one month she was entirely asymptomatic; the haemoglobin had risen to $12.1 \mathrm{~g} / \mathrm{dl}$ and the ESR fallen to $33 \mathrm{~mm}$ in the first hour. We later reduced the dose of prednisolone with no untoward effects. At 18 months follow-up she remained well and euthyroid and was taking $2.5 \mathrm{mg}$ prednisolone and $200 \mu \mathrm{g}$ thyroxine daily.

\section{Comment}

This patient presented with the clinical features of hypothyroidism, and the diagnosis was confirmed by the findings of a goitre, strongly positive antithyroid antibody titres, low PBI, and subnormal thyroidal radioiodine uptake. The coexistence of giant-cell arteritis was suspected from the history of temporal headaches of recent onset, and, although the temporal arteries were clinically normal, the histological features on biopsy were typical of giant-cell arteritis. The protean manifestations of hypothyroidism and giant-cell arteritis are well known, and this case illustrates the importance of recognising their possible coexistence in elderly patients, as both conditions are eminently treatable.

The simultaneous presentation of giant-cell arteritis and hypothyroidism has not previously been reported. Polymyalgia rheumatica, however, which is closely related to giant-cell arteritis, was found to co-exist with thyroiditis and hypothyroidism in an elderly woman. ${ }^{3}$ In addition, Niarchos and Finn $^{4}$ described an association between hypothyroidism and abdominal aneurysm and speculated that the arterial lesions were related to an underlying immunological mechanism. In a retrospective survey, Thomas and $\mathrm{Croft}^{5}$ reported a higher incidence of thyrotoxicosis but not of hypothyroidism in a group of women with giant-cell arteritis than in a control group.

The coexistence of giant-cell arteritis and autoimmune thyroiditis with hypothyroidism suggests a common cause, and further studies may contribute to our understanding of the pathogenesis of giant-cell arteritis.

1 Mowat, A G, and Hazleman, B L, fournal of Rheumatology, 1974, 1, 190. 2 Liang, G C, Simkin, P A, and Mannik, M, Annals of Internal Medicine, $1974,81,19$.

3 Fauchald, P, Rygvold, O, and Øystese, B, Annals of Internal Medicine, 1972, 77, 845.

- Niarchos, A P, and Finn, R, British Medical fournal, 1973, 4, 110.

s Thomas, R D, and Croft, D N, British Medical fournal, 1974, 2, 408.

(Accepted 18 March 1977)

University Department of Therapeutics and Clinical Pharmacology, Aberdeen AB9 2ZD

J HOW, MB, MRCP, lecturer

P D BEWSHER, MD, FRCP, senior lecturer

W WALKER, MA, FRCP, regius professor
Acanthocytes, or spiky red cells, in neurological disorders have been described in association with normal serum lipoproteins, ${ }^{1-3}$ hypobetalipoproteinaemia," and abetalipoproteinaemia. ${ }^{5}$ These cells are morphologically indistinguishable from "burr" cells, or "spur" cells in American reports (acanthos, thorn). The third family in the United Kingdom with normolipoproteinaemic acanthocytosis is described here.

\section{Benign normolipoproteinaemic acanthocytosis}

